\title{
The Jewish Setting of the Epistle of James
}

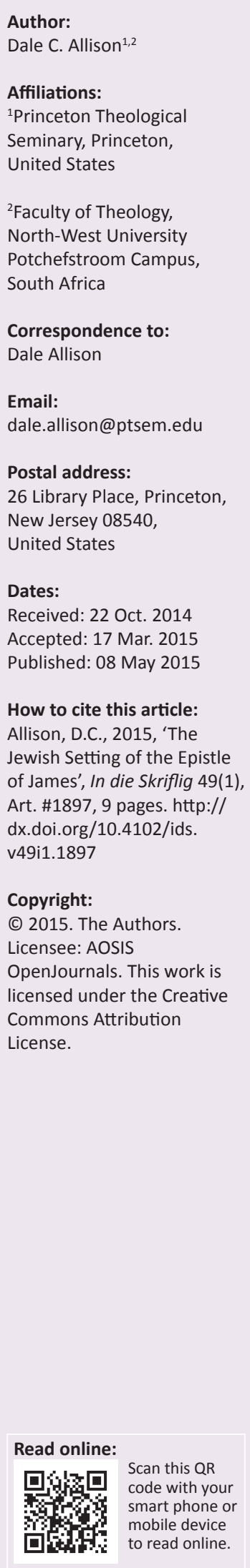

Many older commentators understood the Epistle of James to address itself to Jews of the diaspora, whether Christian or not. Although few modern scholars have seriously reckoned with this possibility, much is to be said for the thesis. It makes sense for example of important features of the epistle that otherwise would remain unclear, such as its dearth of explicit Christology, its seeming lack of distinctive Christian sentiments, and its thoroughly Jewish orientation. The author was a Jewish Christian still hoping for a Christian place within the Jewish synagogue; he wished for irenic relations with those who did not confess Jesus to be the Messiah. He was thus intentionally quiescent about much for apologetical purposes, a strategy with clear parallels in other ancient Christian literature.

Die Joodse agtergrond van die Jakobusbrief. Die Jakobusbrief is deur baie van die ouer kommentaarskrywers gesien as 'n selfverklarende geskrif aan die Jode van die diaspora - hetsy Christene of nie-Christene. Hoewel van die moderne navorsers heelhartig daarmee saamstem, bestaan daar heelwat twyfel oor hierdie siening. Dit maak egter sin ten opsigte van sekere belangrike beskrywings van die brief wat andersins onverklaarbaar sou wees soos die gebrek aan uitdruklike Christologie, die skynbare gebrek aan kenmerkende Christelike sentimente en die grondige Joodse oriëntering daarvan. Die skrywer was 'n Joodse Christen wat steeds gehoop het vir erkenning binne die Joodse sinagoge en versoenende verhoudings met diegene wat nie vir Jesus as die Messias erken het nie, verlang het. Dus was hy met voorbedagde rade baie stil oor baie dinge om apologetiese redes - 'n strategie wat duidelike parallelle met ander antieke Christelike literatuur toon.

\section{Introduction}

The Epistle of James generates, from the historical-critical point of view, a slew of challenging questions. Who wrote it? Was it James the brother of Jesus, or did someone write in his name? Or was the author some lesser known James who was only later mistaken for his more famous namesake? Informed scholars promote each possibility (Allison 2013a:113-114).

When was James written? If the brother of Jesus wrote it, it must have appeared before he died, which means before the mid-60s. If, however, he did not write it, the book could be very late. Some informed voices put it in the 2nd century - even the mid-second century (e.g. Nienhuis 2007).

What sort of a book is it? The vast majority of Greek manuscripts include the word 'epistle' (epistolè) in the inscription or subscription. Many, however, doubt the fact that it really is a letter. The book lacks a letter's ending - it just stops; it has no conclusion at all - and it conveys no personal messages. Perhaps, then, it is, as some have urged, a bit like the book of Proverbs: a collection of general moral exhortation, of eclectic and not always closely related sayings and paragraphs of exhortation.

There are also other options: Maybe James is the record of a sermon or a sort of midrash, an elaboration and application of certain Old Testament scriptures. It could also be a collection of catechetical materials. All of these possibilities and more appear in the critical literature (see Allison 2013a:71-76).

Where was James written? Opinion is split between Palestine and the diaspora. There is no further agreement regarding the literary relationships between James and other early Christian writings. There are striking parallels between James and some of Paul's letters. Does James know and respond to Paul, or do the two writers independently make use of similar traditions instead? There are likewise close parallels between James and the 2nd century Shepherd of Hermas. 
The question likewise arises here: Does one text know the other or do they share so much, because they depend upon common traditions or even written sources? Moreover, what of the remarkable, extensive correlations between James and 1 Peter? Some think that 1 Peter borrows from James; some think that James borrows from 1 Peter; some think that both borrow from common Christian tradition (see Allison 2013a:62-70)

Finally, there is the biggest question of all: What was this book designed to do and in what historical context? Some hold that James is the response of Jesus' brother to the unwelcome effects that some of Paul's ideas, or perhaps even some of his letters, were having. Others - indeed, the majority of modern German scholars - maintain that James represents in large measure a reaction not to Paul, but to later, post-70 (mis)interpretations of Paul and to the ethical lapses they encouraged (e.g. Burchard 2000). Yet another idea is that our author, sensing the revolutionary tendencies that eventuated in the Jewish war, sought an alternative in hope and patience that waits upon divine intervention (e.g. Martin 1988). Then again, maybe James reacts against Jewish Christians associated with the Essenes or maybe he opposes some form of Gnosticism. Another possibility could be that he counters Marcion, or interprets a primitive collection of Catholic Epistles. Beyond all this, there is the thesis, nurtured by the influential commentary of Dibelius (1976), that James was not written for a particular concrete occasion, as is evidenced by the fact that there is no trace of any personal relationship between the author and his audience.

What should one conclude?

Perhaps it would be prudent, given the extraordinary differences in learned judgement, to refrain from drawing too many conclusions regarding James. Some historical mysteries simply cannot be solved, because too few clues have come down to us. Nonetheless, having spent much of the last two decades working on the Epistle, it is my conviction that some proposals are more plausible than others. It is therefore the purpose of this article to introduce some of those proposals. ${ }^{1}$

\section{Unexpected silences}

I begin with Luther who once claimed (1960:396) that, although James 'names Christ', he 'teaches nothing about him, but only speaks of general faith in God'. Luther even went so far as to assert in one place (1967:424) that 'some Jew wrote' the letter of James 'who probably learned about Christian people but never encountered any'.

Why would Luther say such things or why would one modern scholar dub James as the least Christian book in the New Testament' (Jülicher 1931:209)? Why would another affirm 'that which is specifically Christian [in it] is surprisingly thin' (Bultmann 1955:143), or another assert that it leaves 'the impression of an almost pre-crucifixion

1.This article serves as introduction to some major conclusions drawn in Allison (2013a). discipleship' (Sidebottom 1967:14) or another claim that it lacks 'any distinctive Christian message' (Kümmel 1975:416)? Why did one 19th century commentator assert that 'the style and manner [of James] are more that of a Jewish prophet than a Christian apostle' (Clarke 1856:1824)?

The reasons for such remarks, which could be multiplied indefinitely, are obvious. Jesus' crucifixion is neither mentioned nor clearly alluded to. Nor is anything said about his resurrection or exaltation. Jesus' deeds are nowhere mentioned, and one searches in vain for any remark upon his character or status as a moral model - a striking omission given the appeals to other moral models, namely Abraham, Rahab, Job and Elijah. Adolf Harnack (1958:490) remarked: James 'does not refer to Jesus Christ where one would expect'. Further, our book says nothing explicit about baptism, about the Lord's Supper or about the fulfillment of prophecy in Jesus Christ. Scholars have, to be sure, found echoes of these things in James, and they have likewise attempted to tease from the book a developed Christology, drawing inferences from what they imagine to be implicit. Yet, the truth remains that, as one recent commentator has arrestingly put it, 'James has more to say about Rahab the prostitute than about Jesus!' (Gench 1996:79).

\section{Explaining the silences}

What explains the silences, which are so strange given James' canonical context? A few earlier scholars decided that James must be a retouched Jewish writing (e.g. Spitta 1896). That is, the letter was, as Luther once imagined, written by a Jew. Some later Christian, who found it congenial, then lightly edited it, adding, above all, the first verse and the name 'Jesus Christ' to 2:1. ${ }^{2}$

No one, to my knowledge however, defends this position today. For, although the thesis of a Jewish original nicely explains some facts, it does not explain others. James, after all, appears in the Christian canon, and it borrows too heavily from traditions we know to have been specifically Christian for it to be non-Christian in origin. For instance, the teaching on oaths in 5:12, 'But above all, my brothers, do not swear, either by heaven or by earth or with any other oath, but let your yes be yes and your no be no, that you may not fall under condemnation', clearly reproduces the same tradition that lies behind Matthew 5:34-37; a tradition that presumably goes back to Jesus and which, in any event, was handed down through Christian channels. Moreover, portions of chapter 2 have their closest verbal and thematic connections in Paul's epistles (Allison 2013b). There are also, as already noted, conspicuous parallels with 1 Peter and the Shepherd of Hermas (Allison 2013a:20-23, 67-68). James is a Christian document.

How else, then, might one account for what our book fails to say? One could posit that the letter is so Christologically understated because of its genre or literary type. Should

2.All references to the Epistle of James will be indicated only by chapters and verses. 
we really expect much theology from a book of moral exhortation with wisdom affinities? The document is an assemblage of imperatives - 'do this, do not do that'. It is not theology proper and unless one is dealing with a systematic presentation of foundational beliefs, one needs not be startled by certain silences. Although Moses is nowhere mentioned in the collection known as Proverbs, would it be prudent to deduce that all the contributors were ignorant of the exodus from Egypt or considered it to be unimportant? Was Paul utterly ignorant of, or wholly uninterested in, the miracles of Jesus about which he says nothing? In such cases surely it was the specific and limited goals of the writers that explain the absence of convictions that were probably of some importance to them. One is not puzzled that the great Pauline themes are absent from Philemon: the occasion of the writing accounts for that well enough. Even in the lengthy Romans, the most systematic of Paul's epistles, the apostle fails to allude to the Lord's Supper or to the foundational tradition about Jesus' resurrection known from 1 Corinthians 15. Maybe then we should not be surprised that James, which is a relatively short book of moral exhortation, has little to say about the saving events of Jesus' life and their mediation through the sacraments.

Genre, however, fails to clarify why James can mention the forgiveness of sins, as he does in 5:15, and yet says nothing about Jesus' atoning death, or elucidates why, when James cites models of behavior, he refers to Abraham (2:21-23), Rahab (2:25), the prophets (5:10), Job (5:11) and Elijah (5:17-18), and not to Jesus. Nor does it help us understand why, even if one regards the 'Jesus Christ' of 2:1 as original (I personally think it is textually quite problematic; Allison 2013a:382-84), our book names 'Jesus' and 'Christ' less often - at most twice - than any other Christian writing of the New Testament period except the diminutive 3 John. Even the 25 verses of Philemon, the 13 verses of 2 John, and the 25 verses of Jude beat the much longer James on this score. Where else in early Christianity do we have an epistle whose Christological elements are so slight that some have excised less than half a dozen words and then declared the result to be a non-Christian document? The appeal to genre does not compel.

Is there another solution? Maybe, one might suggest, our perplexity over James's content is occasioned only by a failure to reckon seriously with the diversity of early Christianity. Maybe we should elucidate James' conspicuous silences by urging that our book represents a type of Christianity akin to what some have glimpsed behind the Sayings Source Q, the hypothetical source of Matthew and Luke, for this document, according to the standard reconstructions, says nothing about Jesus' death or resurrection.

Although others might wish to move in this direction, I do not. The traditions taken up into Paul's epistles, traditions that developed during the earliest Christian period to which we have access, are full of Christological assertions and emphases; and in them Jesus' death, resurrection and exaltation are fundamental. I, for one, doubt that we have, apart from some very conjectural reconstructions of a few very hypothetical communities, really know of any other sort of primitive Christianity, that is, one without such Christological assertions and emphases or focus upon Jesus' passion and vindication.

More importantly, when one carefully examines the Christian parallels to James, time after time one discovers the very peculiar fact that he alone lacks Christological elements. For instance, James' first paragraph, 1:2-4, in which our author exhorts his readers to count it all joy when they face various trials, because the testing of faith produces steadfastness, which leads to being complete and lacking in nothing, has very close parallels in Romans 5 and 1 Peter 1 . Whereas the relevant verses in 1 Peter 1 and Romans 5 name Jesus Christ and are in other ways explicitly Christian that is not true of James (see Allison 2013a:140-141). This odd phenomenon recurs as one works through our text, that is, James takes up traditions that elsewhere in the New Testament appear in Christological dress. Yet, in his gospel the Christology is not there. It is as though James deliberately avoids being too Christian about things.

Again, then, what can be the explanation? A few have offered that James must represent a very primitive or undeveloped theology. But was there ever a Christian theology that said nothing about Jesus' death and resurrection or ascension or was altogether lacking in the ways our epistle is? Maybe we should be asking whether there might be some good rhyme or reason for a Christian to be deliberately quiet about some important Christian matters.

\section{Additional considerations}

In order to set the stage for my case that James is indeed consciously quiet about much, that the book is silent by design, I begin with a series of observations:

1. James does not explicitly address itself to Christians. The first line has this: 'James, a servant of God and of the Lord Jesus Christ, To the twelve tribes in the Dispersion: Greeting.' There is nothing here about a church or churches. James quite literally addresses itself to 'the twelve tribes in the Dispersion'. Many believe that this is a figurative way of speaking about Christianity throughout the world. ${ }^{3}$ I prefer to take the address at face value. Cadoux (1944) wrote long ago regarding James 1:1:

Christians to-day believe that the Church has inherited the privileges of Israel, but if they found a circular letter beginning, 'My dear fellow Jews', they would unhesitatingly conclude that it was written by a Jew to Jews; nor is there less reason for taking the address of this Epistle to mean what it says. (p. 11)

Unlike the opening of 1 Peter, the first verse in James contains no hint that it should be given figurative sense or applied to the churches. Nor does any other part of 
the letter, from which all allegorical interpretation is absent, contain such a hint. James 1:1 does not explicitly refer to Christians as its addressees. It rather, on its face, addresses Jews in the diaspora. Those who understand this as a letter addressed to Christians must read into the first verse what is not there.

A literal reading of 1:1, whilst not common at the present exegetical moment, is scarcely idiosyncratic. Many competent readers have inferred that our letter was not written to Christians, or at not least exclusively to Christians, but that it addresses Jews, whether Christian or not. This view was particularly popular in the 17th and 18th centuries, but it is appears as early as the Venerable Bede and will also be sponsored in John Kloppenborg's forthcoming commentary in Hermeneia (see Allison 2013a:116).

2. There is no sign of a Gentile audience whereas much lines up with a Jewish one. James 2:21 calls Abraham 'our father' without any hint that the expression bears a transferred sense so that it includes Gentiles or Gentile Christians. The meeting place or gathering of the readers is called a 'synagogue' (2:2). In 2:19, the readers' faith is embodied, not in a confession about Jesus, but in the Shema: 'You believe that God is one', - this being a clear reference to Deuteronomy 6:4: 'The Lord our God, the Lord is one'. Moreover, the writer calls God 'the Lord Sabaoth' without explanation (5:4), and all the moral exemplars are drawn from Jewish tradition - Abraham, Rahab, the prophets, Job and Elijah. There is no mention of idolatry, drunkenness or other sins that early Christian writers often imagined to be characteristic of Gentiles. The Jewish ethos is ubiquitous. In sum, our book seems to be addressed to Jews.

3. James contains neither Christian salutation nor Christian benediction. This is not what we anticipate from an early Christian epistle. The odd circumstance would, however, be explained if the author did not have only Christian readers in mind.

4. With the exception of $2: 1$, which is textually uncertain, readers are nowhere explicitly characterised as followers of, or believers in Jesus. Put otherwise, if one brackets the 'Jesus Christ' of 2:1, which, on grammatical grounds, has often been thought of as secondary, readers, as opposed to the author (1:1), are nowhere referred to as being followers of, or believers in Jesus.

5. As a matter of exegetical history, many have found parts of James peculiar if taken to be addressed directly to Christians (see Allison 2013a:592, 646-648). This is true above all of chapters 4 and 5 . Here readers are called to submit themselves to God, to cleanse their hands, to purify their minds, and to mourn and weep. The reason is that they are 'adulterers' (4:4) and 'sinners' (4:8) - that they are friends of the world and enemies of God (4:4). They are even guilty of murder (5:6). In calling them to account, James appeals to Scripture and Jewish tradition, not to the gift of the Holy Spirit or to specifically Christian convictions. Furthermore, those denounced in chapter 5 especially seem past repentance. They have fattened their hearts for slaughter, and their flesh will be eaten like fire
(5:1-5). Many have understandably doubted that these are believers in Jesus. Are there, in the first 100 years of Christianity, any other texts in which a Christian accuses Christians of murder? It is telling that most who think of James as addressed exclusively to Christians typically hold that, at least in chapters 4 and 5, James, like some of the canonical Hebrew prophets, is addressing those not present, that is, people who will never hear or read his letter (see Dibelius 1976:231, 235). This, however, is to concede that our writing does not consistently or in its entirety read well as a discourse to Christians.

6. Commentators debate the identity of the rich in 2:1-7, which reads:

if a man with gold rings and in fine clothing comes into your assembly, and a poor man in shabby clothing also comes in, and you pay attention to the one who wears the fine clothing and say, 'Have a seat here, please', while you say to the poor man, 'Stand there', or, 'Sit at my feet', have you not made distinctions among yourselves, and become judges with evil thoughts? Listen, my beloved brethren. Has not God chosen those who are poor in the world to be rich in faith and heirs of the kingdom which he has promised to those who love him? But you have dishonored the poor man. Is it not the rich who oppress you, is it not they who drag you into court? Is it not they who blaspheme that honorable name which was invoked over you?

Who are these rich people? That they are Christians ill fits the fact that they blaspheme 'the good name that was called over you'. Maybe, then, 'synagogue' should be given its natural sense, and perhaps we should think not of a Christian service of worship, but rather of a Jewish building or gathering, one with both Jewish and Christian participants (see Allison 2013a:376-77).

7. The chief reason usually given for refusing to see James as addressed or partly addressed to non-Christian Jews is the claim that several verses presuppose a Christian readership. James 1:18 speaks of those 'brought forth by the word of truth that we should be a kind of first fruits of his creatures'. Is this not about Christian regeneration? James 5:7-8 refers to 'the parousia of the Lord'. Is this not a clear reference to the second coming of Jesus? Furthermore, 5:14 speaks about 'the elders of the ecclesia'. Are these not obviously church officers?

A detailed examination of these texts is beyond the current article. I can only observe a couple of things. Firstly, not one of the verses cited the names Jesus Christ. Therefore, one is still left with the question of why everything that we think of as being characteristically Christian, remains at best implicit.

Secondly, and this is an arresting fact, in each case the history of interpretation reveals that the relevant texts can be and have been read in more than one way, and in ways that see specifically Christian theology recede. The language of 1:18 has moved many expositors to think not of Christian rebirth through the gospel, but instead either of humanity's creation by God's word or the new creation of Israel through the giving of Torah on Sinai (see Allison 2013a:255-256). As for 
the expression, 'the parousia of the Lord' - not, and it should be emphasised, 'the parousia of Jesus' - it is almost certainly a Christian formulation. Yet, it is striking that, in the verses that immediately precede and in those that immediately follow, 'the Lord' is God, not Jesus $(5: 4,11)$. As a result some exegetes have thought that the Lord is God also in 5:7-8 (Allison 2013a:699). As for 5:14, 'Is any among you sick? Let him call for the elders of the ecclesia', James mentions neither 'deacons' nor 'bishops', and the Septuagint speaks of both Jewish 'ecclesia' and Jewish 'elders' (see Allison 2013a:755757). The two words are not in and of themselves, or even when put together, Christian (cf. Ps 106:32 - LXX; 2 Esdras 10:8; Jl 2:16 - LXX).

The strange truth is that, aside from 1:1 and the textually dubious 2:1, James, although certainly written by a believer in Jesus, explicitly says nothing distinctively Christian. It is as though the readers are neither assumed nor required to be members of the church themselves. The whole epistle rather stays within, or at least could be read within, a Jewish frame of reference. One modern scholar has opined that 'every sentence ... could have been written by a proto-rabbi' (Sigal 1980:424).

Readers of James often miss this, because, consciously or not, they are canonical readers, assuming that James must be saying what the New Testament says elsewhere, but he does not. He remains resolutely silent in remarkable ways, even when we would expect otherwise.

\section{Two old proposals}

At this point, and as a way forward, I wish to introduce the work of two older scholars.

Over a 100 years ago, J.H. Moulton (1907) observed that, after the author of James declares himself to be a servant of Jesus Christ:

he drops all overt reference to Christian faith, and only names the Master in a verse [2:1] where the forced order of the words raises an extremely strong presumption of a gloss. (p. 45)

According to Moulton (1907), the explanation for this lack of overt reference to Christian ideas is that the letter is addressed to Jews:

The 'Twelve Tribes of the Dispersion', of course, most naturally suggests such a destination. The 'synagogue' of ii. 2 will then be Jewish, and the rich men who are so sternly denounced will be more easily found than if we have to seek them in a Christian community of any date prior to the age of Constantine. (p. 46)

Why, then, the absence of specifically Christian doctrine? For Moulton (1907), it was part of a missionary strategy. Most Jews:

would be deaf to all argument which even named the Crucified, and he who would reach them must try another way. Could there be a better way than to write as a Jew to Jews, threading the pearls of Christ's own teaching on a string of miscellaneous exhortation, all tending to shame them out of a blind un-

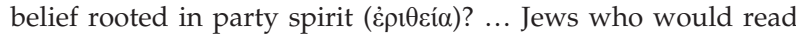
this Epistle could often without great difficulty be led on to read such a book as our First Gospel, in which they would learn with surprise that many of the sayings they had accepted as heavenly wisdom, when purporting to come from a pious and orthodox Jew, were really due to Him whom all orthodox Jews had agreed never to hear. (p. 47)

In making this proposal, Moulton (1907) cited a parallel from 19th century India. A Christian missionary, he tells us, published a tract consisting of nothing but material from the Mahābhārata, a Hindu scripture - material that the missionary found congruent with Christian belief. The purpose was to make Hindus more open to the appeal of the Christian message:

The Epistle of James was a composition of this class, a Christian's appeal to non-Christians, which veils Christian terms and names in order to insinuate Christian truth into prejudiced minds. (pp. 49, 50)

This is a provocative reading of James. It is, however, not free of problems. For one thing, one doubts that James was penned for non-Christian Jews alone. The book does nothing to exclude Christian Jews, who would be included amongst the addressees in 1:1, and so much of James makes sense as practical advice for believers in Jesus that it seems unwise to imagine that the letter was intended only for outsiders.

Another difficulty for Moulton is his assumption that a Christian wishing or purporting to communicate with non-Christian Jews could have had only one goal in mind, namely to proselytise them. This seems a narrow view. Do we really know that early followers of Jesus, in all times and places, sought the conversion of Jews to Christian doctrine? James, in any event, drops no hint about missionising, and one can, without difficulty, imagine situations in which stressing similarities rather than differences might have been the prudent course (see below). Indeed, is that not what one might expect of Christian Jews who wanted, despite opposition, to continue attending synagogue?

a. H. McNeile (1923) attempted to remedy the deficiencies in Moulton's thesis. McNeile agreed that James' Christianity is intentionally quiet and that our letter addresses itself to Jews. Unlike Moulton, he plausibly held that our epistle addresses both Jews and Christians. Why then the silences? 'There is little doubt that the writer is himself a Christian, but in his desire to reach the widest possible public he studiously selects language acceptable to Jew and Christian alike' (McNeile 1923:90). To that public he wanted 'to prove nothing doctrinal, and to "proselytize" no one, but to show that the highest standard of ethics for Jew and for Christian could be one and the same' (McNeile 1923:95). In building his case, McNeile rightly observed how often James is ambiguous, that is, how many times a Christian could take something one way, a non-Christian Jew another. 
b. Although McNeile's argument seems more plausible than that of Moulton, he added nothing to the latter's comparative material, which consisted solely of a modern Christian tract consisting of nothing but material from the Mahābhärata. That scarcely suffices to ground a thesis about an ancient Christian text.

\section{Ancient parallels}

It is obvious that writers in all cultures regularly accommodate themselves in one way or another to projected audiences. Modern textbooks, for instance, are written on the level of anticipated students, and children's books avoid long words. Are there, however, any parallels in the ancient world to the sort of thing that Moulton and McNeile envisaged? That is, are there any examples, closer to James' time and place than Moulton's illustration, of religious individuals who, for this or that reason, found occasion to keep their religious convictions, or at least some of them, wholly in the background, or in the background for long stretches? There were:

1. In one place, Origen (Commentary on Jeremiah 20.5), tells us that, when in conversation with prejudiced pagans, he would hide his Christianity. That is, he would propound Christian teaching, but not speak of 'Christ' or 'Christians' unless or until he had his listener's respect and attention in which case he would then plainly declare his affiliation and the source of his wisdom.

2. The Sentences of Sextus is a second century collection of 451 sayings, mostly ethical injunctions. Although its author is unknown, he was clearly Christian; yet, not explicitly so. As Jerome observed, although the Sentences are Christian, they fail to mention the prophets, the patriarchs, the apostles, or Christ' (Epistle 133.3). So the writer attempted to communicate by consciously setting aside overt Christian assertions. Why might he have done such a thing? The answer is not obvious. Henry Chadwick (1959), however, thought that Sextus sought:

\footnotetext{
to bring the moral wisdom of the Greek sages under the wing of the church to whom all truth belongs. With adjustments here and there the language of Stoic or Pythagorean wisdom could pass in Christian circles. Pythagoras is ours might be his motto .... The purpose was probably apologetic .... Christianity brings to actuality what is potentially already there. The soul is naturally Christian. (pp. 160-161)
}

This seems the best bet. In any case, here is a Christian collection of wise sayings that refrains from making explicitly Christian theological assertions.

3. The Christian apologist, Lactantius, who lived in the 3rd and 4th centuries, mentions God throughout the first three books of his Divine Institutes, but nowhere he names 'Jesus' or 'Christ'. In these very long sections, Christian doctrine is off to the side as Lactantius attempts to argue with pagans on their own ground, offering criticisms of polytheism and secular philosophy that derive from generally accepted premises. A similar silence marks another one of Lactantius' books, namely On God's workmanship. In this, Lactantius argues about the human body on the basis of reason, not Christian theology. The book lacks any distinctively Christian ideas. In two different works, then, Lactantius deemed it fitting to construct arguments that would speak to people outside of the church.

4. One finds something very similar in the earlier, 2nd century apologies of Athenagoras and Tatian. These fail to name Jesus or to speak of 'Christ', and they appear to support little more than monotheism and moral responsibility. They do argue for the expectation of resurrection and judgement, but they are uninterested in Jesus as a human figure in the corporate life of the Christian community or in the deeper resources and expression of early Christian piety. The reason is that their projects were focused on specific criticism, and they wanted to answer their critics in terms those critics could understand and accept. The apologists were not being disingenuous, but their task was of limited scope. They were Christians, and they were defending Christianity, but they deliberately left much that is distinctively Christian out of account.

5. Even more striking are the extant books of the 2nd century bishop, Theophilus of Antioch. Written to a pagan friend of the bishop, these books pass over the incarnation, fail to refer to the ministry of Jesus, and make no allusion to his passion. The canonical gospels are used only for their moral teachings. Moreover, Theophilus can, incredibly, define 'Christian' without naming Jesus Christ, and he can defend the idea of resurrection without referring to Jesus' resurrection. Theophilus promotes, evidently for apologetical purposes, what has been called 'a Christianity without Christ' (Bentivegna 1975). One commentator has remarked that a sympathetic reader could have become a convert to Judaism as readily as to Christianity (Laeuchli 1962:165-166).

6. Pseudo-Phocylides is a collection of sayings presumably composed around the turn of the era. The author knew the Septuagint, and his work is undeniably Jewish. At the same time, 'it looks as if he did his utmost to conceal the Jewish origin of many of his rules of conduct' (Van der Horst 1978:189). Why the concealment? One explanation of Van der Horst (1988) is that:

as a Jewish writer, he tried to provide a "pagan" text that could be used safely in Jewish schools to satisfy Jewish parents who wanted their children to be trained in the classical pagan authors.' (p. 16)

Another suggestion is that he hoped for more than Jewish readers. Whatever the truth, here is an illustration from the Jewish world of somebody keeping intentionally quiet about all sorts of religious beliefs and practices that he clearly knew and valued.

7. There are two examples of what one might call Christian reticence in the New Testament itself. Acts contains two speeches in which Christian elements are missing until the very end, and even then the language remains oblique. Stephen's speech in Acts 7 lacks all Christology until the next to the last verse when it speaks, not of 
the crucifixion of Jesus Christ, but of the killing of 'the righteous one'. Paul's speech in Athens is similar. It seeks to explicate the religiosity of the Athenians and only at the end speaks of 'a man' whom God has appointed and raised from the dead. In both cases, Luke thinks it appropriate to present two of his heroes as discoursing at length on religious subjects without, at least initially, being explicitly Christian. In the case of Acts 17, this is a missionary strategy.

\section{The silences of James}

It is clear that what Moulton and McNeile envisaged for James has parallels in the ancient world. That is, we know of religious people, including Christians, who, for various reasons, found occasion in their writings to keep a discrete silence about some of their most important religious convictions. To suggest that the author of James did the same, that he decided for some reason not to wear his religious heart on his sleeve, is not, then, unthinkable. Why, however, might he have done this?

The letter remains cryptic on any reading, but the best hypothesis seems to be that James represents Christian Jews who did not define themselves over against Judaism. The epistle - whether authored by the brother of Jesus or by someone in his name - emerged from a Christ-oriented group that still attended synagogue and wished to maintain irenic relations with Jews who did not share their belief that Jesus was the Messiah.

In such a context, James makes sense. The emphasis upon convictions rooted in the common religiosity of the wisdom literature and the prophets as well as the omission of potentially divisive Christian affirmations, would potentially make for good will amongst those in the synagogue. It is suggestive that a modern theologian (Hogan 1997) has written that:

James' grounding of his moral exhortations in theological rather than Christological principles provides a genuine bridge between Christians and Jews who share a belief in the One God, Creator, Lawgiver and Judge. (p. 91)

Although this is a contemporary theological judgement, it may harmonise with the original intention of the author of James, which was to persuade sympathetic readers that the differences between his Christian version of Judaism and other forms were not so great. One recalls a line spoken by Peter in the Pseudo-Clementine Recognitions: 'only on this is there a difference between us, we who believe in Jesus, and those sons of our faith who do not believe' (Ps.-Clementine Recognitions 1.43.2 Syriac).

The letter of James communicates, amongst other things, that Jesus' followers are not apostates from Judaism, but rather faithful members of the synagogue who live according to the Jewish moral tradition, are faithful to Torah, and oppose those who want - as no doubt was rumored of some
Christians - to divide faith from works (see 2:14-26). This is why he draws lines not between Judaism and Christianity, but rather between true and false religion.

There is a parallel in a Dead Sea Scroll, the Halakhic Letter, 4QMMT. This Qumran text differs from other Qumran texts in that it addresses outsiders. Collins (1997) suggests that it was intended to be read outside the group of the author as well as within, and it:

makes no attempt to argue from the experience of the sect or from its idiosyncratic theology, since the recipients of the letter could not be expected to accept such arguments. Instead, 4QMMT is framed in terms that might in principle be persuasive to any Jew. It appeals primarily to the Law of Moses. (p. 81)

In other words, the letter, which appears to have been written at a time when the Qumran community was still hopeful of reconciliation with an institutionalised opposition - probably some part of the Jerusalem establishment - speaks in a language understandable to all learned Jews, even though its purpose is to describe sectarian laws.

Despite the parallel, one must not overlook that James is often polemical. The attacks in chapters 4 and 5 are in fact vicious. They are not, however, assaults upon the synagogue as such. From James' viewpoint, the synagogue has at least three sorts of members. There are Christian Jews (represented by 'the poor' $^{\prime}$ of $\left.2: 1-7\right)$, there are rich oppressors (2:1-7; 4:1-5:6), and there are those belonging to neither group, whose sympathy James seeks to gain or preserve. He wants non-Christian Jews in his synagogue to recognise in the opposition to Christians the unjust oppression of the poor so fervently condemned by the Hebrew prophets. James rails in the hope that others will see things as he does. He seeks not to proselytise, but to promote tolerance for, and understanding of, his own group to gain sympathy for Christians in a context where there is perhaps growing antipathy, but not yet formal expulsion (see Allison 2011). This is why James' polemic is not against false teaching, but against 'arrogance ... anger, and the criticizing and insulting of others in the community, directly or otherwise' (Chester 1994:29). It is also why the epistle is so much concerned with 'the unity and proper functioning of the [religious] community' (Keith 2003:24). James wants to foster in the synagogue peace, gentleness, mercy and impartiality (3:16-18), which should leave room for the Christian Jews for whom he speaks.

To simplify, James has above all three groups in mind. Firstly, there are those who are, in his view, mistreated and suffering; they are primarily or exclusively the followers of Jesus. Secondly, there are those who mistreat them, presumably some group of non-Christian Jews, rich or affiliation with rich individuals. Thirdly, there are those who belong to neither of those groups, and it is their sympathy James wishes to gain or strengthen.

Again there is a formal parallel with the Qumran text, 4QMMT, for it too envisages three groups. There is the 
group that is defended - members of the Qumran sect; then there is the group that is criticised - probably Jewish leaders in Jerusalem;and then there is the group of potential sympathisers.

\section{Christians within Judaism}

The sort of Christianity envisaged here for James is related to one of the groups some scholars have detected behind John's Gospel. J. Louis Martyn (1979) famously argued that John - above all chapter 9 - attests to the existence of Jews who attended synagogue and believed in Jesus, but did not proselytise. His case has convinced many, including Raymond Brown, for whom the so-called 'Crypto-Christians' had 'little taste for polemics against the synagogue'. They rather sought to 'work from within to bring ... offended synagogue leaders back to a tolerance toward Christians that had previously existed' (Brown 1979:71-73). Nicodemus may be a symbol of such folk: He comes to Jesus by night, obviously so that certain people will not know of his sympathies. John 12:42 also could stand for such people, for here we read that many Jewish authorities believed in Jesus, but 'for fear of the Pharisees did not confess it, for fear of being put out of the synagogue'.

Even if one does not find Martyn persuasive, we certainly have evidence that, at least in later times, some Jews with Christian convictions, wishing to stay on friendly terms with Jews who did not share their convictions and not always flaunt their beliefs about Jesus. Epiphanius (Panarion 30.9.2-3) reports that a certain Josephus of his acquaintance was encouraged by 'an elderly scholar of the law', but only privately, to confess faith in Jesus Christ. Epiphanius likewise purports (Panarion 30.9.4-6) to have known another Jew who was learned in the law, loved Christians, spent time in their company and believed in the incarnation; Yet, 'from fear of the Jews', the man remained a non-Christian Jew. Then there is the story in the Pseudo-Clementine Recognitions, regarding a certain Jewish authority, Gamaliel I, who was 'secretly' a believer in Jesus and used his prominent position to assist Christians $(1.65 .2 ; 66.4)$. Although this is a fiction, it expresses someone's belief that faith in Jesus did not necessarily entail evangelistic activity or abandoning Judaism.

In this connection the tale of the martyrdom of James in a fragment of the 2nd-century writer, Hegesippus, is most intriguing. This has 'the Jews and the scribes and the Pharisees' asking James to restrain the people who have gone astray by belief in Jesus as the Messiah:

Be good enough to make the facts about Jesus clear to all who come for Passover. We all accept what you say; we can vouch for it, and so can all the people, that you are a righteous man and do not show favoritism. So make it clear to the crowd that they must not go astray as regards Jesus.

In the event, James publicly confesses Jesus, whereupon the scribes and Pharisees realise their mistake (Hegesippus according to Eusebius, Ecclesiastical History 2.23.4-18).
This is a remarkable legend. It implies that, before James made his public statement shortly before his death, some in Jerusalem knew of him and even admired him and yet were either unaware of his Christian affiliation or thought his beliefs about Jesus innocuous. In other words, until the time of his execution, James, according to this tale, successfully passed himself off to many as a pious Jew. I suggest we have the same memory or at least image of the brother of Jesus that we find in the epistle of James.

\section{Conclusion}

Recent work on ancient Judaism and Christianity has established that the two entities were not as clearly distinct as once taken for granted. The Epistle of James, as I read it, accords with such work. Our author, although professing to be a Christian, does not identify his readers as such. Hence, the general address to the 12 tribes: he evidently still hopes for an audience with non-Christian Jews. James is thus a sort of apology. It addresses Jews, which includes those who share the author's Christian convictions as well as those who do not. It also has a two-fold purpose: edification for Christian Jews and clarification for non-Christian Jews.

On this view, we can understand why James is so two-faced, why it seems so Christian and yet is so resolutely mute on peculiarly Christian themes. We can also understand why it contains so many passages that could be taken one way by a Christian and another by a non-Christian. James reflects a Christian group still battling for its place within the Jewish community; a group that wishes to remain faithful members of the synagogue to be both Jew and Christian. It is telling that James Parkes (1961:58), who dedicated so much of his life to improving relations between Jews and Christians, found James to be 'in many ways the most attractive of Apostolic writings'.

On the reading of James proposed herein, it is clear why the book is so Jewish, why it is largely a compilation of traditions, and why it is often difficult to trace a logical connection between the larger units. James is not an argument, but a presentation - a sort of sampler. It is someone's collection of what he wants Jews in the synagogue to know about Christians. It is designed to look Jewish and to look traditional, because it highlights what Jews and Christians have in common.

\section{Acknowledgements Competing interests}

The author declares that he has no financial or personal relationship(s) that may have inappropriately influenced him in writing this article.

\section{References}

Allison, D.C., 2011, 'Blessing God and Cursing People: Jas 3:9-10', Journal of Biblical Literature 130, 397-405.

Allison, D.C., 2013a, A Critical and Exegetical Commentary on the Epistle of James, T\&T Clark, New York/London/New Delhi/Sydney, Bloomsbury. (International Critical Commentary) 
Allison, D.C., 2013b, 'Jas 2:14-26: Polemic against Paul, Apology for James', in T. Nicklas, A. Merkt \& J. Verheyden (eds.), Ancient and New Perspectives on Paul, pp. 123-149, Vandenhoeck \& Ruprecht, Göttingen.

Bentivegna, J., 1975, 'A Christianity without Christ by Theophilus of Antioch', in E.A Livingstone (ed.), Studia Patristica, vol. 13, pp. 106-130, Akademie Verlag, Berlin

Brown, R.E., 1979, The Community of the Beloved Disciple, Paulist Press, New York.

Bultmann, R., 1955, Theology of the New Testament, vol. 2, Charles Scribner's Sons, New York.

Burchard, C., 2000, Der Jakobusbrief, Mohr Siebeck, Tübingen.

Cadoux, A.T., 1944, The Thought of St. James, James Clarke, London.

Chester, A., 1994, 'The Theology of James', in A. Chester \& R.P. Martin (eds.), The Theology of the Letters of James, Peter, and Jude, pp. 1-62, Cambridge University Press, Cambridge, UK/New York.

Clarke, 1856, The New Testament of our Lord and Saviour Jesus Christ, vol. 2, G. Lane \& C.B. Tippett, London.

Chadwick, H., 1959, The Sentences of Sextus, Cambridge University Press, Cambridge. http://dx.doi.org/10.1017/CBO9780511470523

Collins, J.J., 1997, 'The Expectation of the End in the Dead Sea Scrolls', in C.A. Evans \& P.W. Flint (eds.), Eschatology, Messianism, and the Dead Sea Scrolls, pp. 74-90, Eerdmans, Grand Rapids, MI.

Dibelius, M., 1976, James, ed. H. Greeven, Fortress, Philadelphia.

Gench, F.T., 1996, Hebrews and James, Westminster John Knox, Louisville.

Harnack, A., 1958, Geschichte der altchristlichen Literature bis Eusebius, Teil II: Die Chronologie, Band I, 2nd ed., J.C. Hinrichs, Leipzig.

Hogan, M., 1997, 'The Law in the Epistle of James', Studien zum Neuen Testament 22, 79-91.

Jülicher, A., 1931, Einleitung in das Neue Testament, J.C.B. Mohr, Tübingen.

Keith, P., 2003, 'Les Destinataires de l'Épître de Jacques', FoiVie 104, 19-27.
Kümmel, W.G., 1975, Introduction to the New Testament, rev. ed., Abingdon, Nashville. Laeuchli, S., 1962, The Language of Faith: An Introduction to the Semantic Dilemma of the Early Church, Abingdon, New York.

Luther, M., 1960, 'Preface to the Epistles of St. James and St. Jude', in Luther's Works, vol. 35, ed. J. Pelikan, Fortress, Philadelphia.

Luther, M., 1967, 'Table Talk', in Luther's Works, vol. 54, ed. J. Pelikan, Philadelphia.

McNeile, A.H., 1923, New Testament Teaching in the Light of St. Paul's, Cambridge University Press, Cambridge.

Marcus, J., 2014, “"The Twelve Tribes in the Diaspora” (James 1.1)', New Testament Studies 60, 433-47. http://dx.doi.org/10.1017/S0028688514000095

Martin, R.P., 1988, James, Waco, TX. (Word Biblical Commentary).

Martyn, J.L., 1979, History and Theology in the Fourth Gospel, rev. ed., Abingdon, Nashville.

Moulton, J.H., 1907, 'Synoptic Studies II. The Epistle of James and the Sayings of Jesus', Expositor 7(4), 45-55.

Nienhuis, D.R., 2007, Not By Paul Alone: The Formation of the Catholic Epistle Collection and the Christian Canon, Baylor University Press, Waco, TX.

Parkes, J., 1961, The Conflict of the Church and the Synagogue, World, Cleveland.

Sidebottom, E.M., 1967, James, Jude and 2 Peter, Nelson, London.

Sigal, P., 1980, The Emergence of Contemporary Judaism: The Foundations of Judaism from Biblical Origins to the Sixth Century A.D., vol. 1, Pickwick Press, Pittsburgh.

Spitta, F., 1896, Zur Geschichte und Litteratur des Urchristentums, Zweiter Band: Der Brief des Jakobus; Studien zum Hirten des Hermas, Vandenhoeck \& Ruprecht, Göttingen.

Van der Horst, P.W., 1978, 'Pseudo-Phocylides and the New Testament', Zeitschrift für die Neutestamentliche Wissenschaft 69, 187-202.

Van der Horst, P.W., 1988, 'Pseudo-Phocylides Revisited', Journal for the Study of the Pseudepigrapha 3, 3-30. http://dx.doi.org/10.1177/095182078800000301 